\title{
Article \\ Cultural Heritage: A Hybrid Framework for Ranking Adaptive Reuse Strategies
}

\author{
Lucia Della Spina
}

check for

updates

Citation: Della Spina, L. Cultural Heritage: A Hybrid Framework for Ranking Adaptive Reuse Strategies. Buildings 2021, 11, 132. https:// doi.org/10.3390/buildings11030132

Academic Editor: Rita Bento

Received: 23 February 2021

Accepted: 16 March 2021

Published: 22 March 2021

Publisher's Note: MDPI stays neutral with regard to jurisdictional claims in published maps and institutional affiliations.

Copyright: (C) 2021 by the author. Licensee MDPI, Basel, Switzerland. This article is an open access article distributed under the terms and conditions of the Creative Commons Attribution (CC BY) license (https:/ / creativecommons.org/licenses/by/ $4.0 /)$.
Department of Cultural Heritage, Architecture and Urban Planning (PAU), Mediterranean University of Reggio Calabria, 89125 Reggio Calabria, Italy; lucia.dellaspina@unirc.it

\begin{abstract}
The purpose of this research is to illustrate, through a case study, a multilevel decisionmaking process able to support the decision maker in optimizing investment choices for the efficient allocation of public resources, with specific reference to recovery and adaptation to the reuse of unused historical public heritage. During the evaluation process, two methods in particular were combined according to a multiphase design: (i) a multi-criteria analysis to identify the Highest and Best Use among alternative reuse scenarios and (ii) a Discounted Dash Flow Analysis to support verification of the financial feasibility of the investment, in the hypothesis of an enhancement concession in a public-private partnership. Each method was applied in parallel to the evolution of the different design scenarios. The results of the study show that hybrid approaches are a promising line of research in the field of evaluation and urban design, applied to cultural heritage.
\end{abstract}

Keywords: cultural heritage; adaptive reuse; Highest and Best Use (HBU); Multi-Criteria Decision Aid (MCDA); financial sustainability; Discounted Cash Flow Analysis (DCFA)

\section{Introduction}

In 2015, the United Nations adopted the 2030 Agenda, which reflects the integrated nature of the current challenges by identifying 17 Sustainable Development Goals (SDGs), divided into 169 targets to be achieved by 2030. Among the SDGs, Objective 11 concerns the scale of cities and human settlements in general as privileged places for innovation and technological progress, in which to develop possible actions and solutions to make them more inclusive, safe, resilient, and sustainable [1,2].

In this perspective, local governments play a primary role in linking the local needs of settled urban communities and the global trends of sustainable development of cities and territories that represent complex systems, in which there are present complex dynamics that are economic, social, cultural, and environmental in nature. The adoption of the principles of the circular economy brings numerous benefits, and the fight against land consumption induces positive effects on human well-being and environmental impact. These principles represent a useful model to reverse the consequences produced by a linear growth model and to minimize the production of waste products and close the process cycles.

In particular, in the perspective of a more sustainable future [3,4], the most important challenges concern better use of urban territory through the reduction of new constructions, reduction of construction and management costs, more efficient use of resources, and improvement of social and environmental conditions through the strengthening of the local economy [5].

In this scenario, it is reasonable to think that future territorial redevelopment projects can base their own idea force, their structural axis, on an open system of social attractors consisting of unused public real estate assets, the enhancement of which also fosters knowledge, use, and fruition, setting itself the objective of activating the effects of regeneration spread over the entire territory of influence, and from this, it receives stimuli and resources to progress [6,7]. 
Making better use of abandoned and unused cultural heritage assets as key resources for sustainable urban development can be interpreted as an effective "circular city" strategy [8]. In adaptive reuse processes, the reuse of an existing building, area, or infrastructure for new and different needs through minimal redevelopment and recovery interventions $[9,10]$ can create new opportunities and dynamics of the urban circular economy [11-13], from "waste places" to "catalyst places" for new opportunities, while producing multidimensional benefits (cultural, economic, environmental, and social), benefits deriving from the recovery of the produced capital, but, above all, to those deriving from the enhancement of the human capital involved [14,15]. In implementing the sustainable development goals according to circular economy models, the adaptive reuse of existing public heritage, both historical and recent, in addition to reducing urban sprawl $[16,17]$, preserves historic buildings from obsolescence, and at the same time the economic and social dynamism effects for cities and territories are significant. The social component plays a fundamental role, as the challenge of recapturing abandoned iconic local spaces can mobilize urban communities with voluntary social initiatives in favor of the reuse of heritage $[14,18,19]$

Currently, abandoned, underutilized, and unused public assets represent a cost for the Public Administration (PA), but as a common good represents an important resource for the territory and the community $[9,10]$, both for the value itself and for the potential multidimensional effects that its enhancement can generate from the cultural, economic, social, and environmental points of view [18].

Within this debate, the concept of adaptive reuse is assuming an increasingly central role as a regenerative process, capable of transforming "waste landscapes" into attractive places $[20,21]$. The Anglo-Saxon term of "adaptive reuse" defines a new way of sustainable urban planning, which reduces land consumption and expansion, in which a primary role is played by interventions on the existing heritage to reactivate those buildings that have lost their original function. Successful heritage interventions trigger positive urban, environmental, and social outcomes [3,22], and help revitalize urban areas through new functions and new socioeconomic actors.

Adaptive reuse is an intervention approach recognized in 2018 at the European level as part of the European year of cultural heritage [23], proving to be an effective approach capable of acting according to the prerogatives described so far, reporting social benefits both economic and cultural at different levels.

Due to the scarcity of public resources, the PA is increasingly committed to involving new operators, activating incentive policies, and promoting shared and transparent processes that involve communities. Different actors-technical, political, economic, public, and private, as well as stakeholders with different and often conflicting objectivesparticipate in the decision-making process. Therefore, there is a need to coordinate and balance different interests to obtain feasible and consistent results [22,23].

The growing demand for public investments, necessary to reactivate the economy of European countries, must be combined with the need to create works that are useful to the community and shared at all levels [24-35]. Rigorous and transparent preliminary analyses able to outsource the needs of the community in advance, as well as the technical, procedural, economic, and managerial obstacles to be faced, are needed [36-39]. In this context, the valuation methodologies, as decision support tools, must be able to function as an integral part of the investment development process, as a support for the optimization of investment choices and as a tool for the efficient allocation of public resources [40,41].

In this framework, an appropriate design of the decision support procedure is important, with the use of methodologies that are as simple and understandable as they are possible, but in which the required input information and the recommendations provided as the output must necessarily be rigorous and accurate. In the literature, there are several examples and methodological applications that have been shown to be appropriate for addressing the complexity of reuse interventions [24-35]. 
This document is organized as follows. In Section 2, the objectives of the research are illustrated. In Section 3, the case study is presented. In Section 4, the framework is illustrated. In Section 5, the methodology is applied to the case study. In Section 6, the results obtained applied to the case study are commented on, and in Section 7, the conclusions of the work are discussed.

\section{Research Aims}

As part of the public-private partnership procedures for the recovery and enhancement of public real estate assets [40-43], the aim of the research is to support the Public Administration (PA), owner of the monastery, in the comparative evaluation of some hypotheses of reuse, aimed at choosing the Highest and Best Use (HBU) of the property with a view of activating a Public-Private Partnership (PPP) procedure through the enhancement concession (EC) tool. The EC is among the PPP procedures [30] characterized by the involvement of private operators in programs for the enhancement of public real estate, in a sustainable perspective $[27,29,32]$.

The resolution of the evaluation problem concerning the enhancement and reuse of historical public heritage allows the verification of both the usefulness of the proposed model and its easy adaptability to the specificities of the case study.

\section{Case Study}

The case study concerns the reuse of a former monastery complex linked to the church of S. Nicola Coracitano, known as Palazzo Stella. It is located in the historic center of Catanzaro (Southern Italy), the main regional capital with regional public activities and services (Figure 1).

As part of the strategic plan, the Municipality of Catanzaro has planned a series of integrated interventions, of which development strategy provides for the enhancement of the historic center, together with the creation of new public services.

The quadrangular complex of the former monastery has undergone numerous interventions, transformations, additions, and alterations over time, induced by the stratification of uses, which have partially distorted its original characteristics. The PA acquired the monastery in 2010, although it has remained unused since 2003.

As mentioned, the property is located in the historic center along a secondary road, away from the main communication routes. The complex consists of three main parts: the former monastery, the church, the theater, and the cloister (Figure 1).

The monastery is over three levels, centered around a central courtyard. On the ground floor (about $1000 \mathrm{~m}^{2}$ ), there is the entrance, the reception, the porch, the common rooms, the kitchen, and the canteen; on the first floor (about $850 \mathrm{~m}^{2}$ ), there are the bedrooms; and on the second floor (about $800 \mathrm{~m}^{2}$ ), there are service areas, common areas, and other rooms.

It is the objective of the Municipality of Catanzaro, owner of the property, to proceed with its enhancement through a PPP procedure, according to the hypothesis of Enhancement Concession (EC), in order to verify its financial sustainability. In the current economic situation, characterized by a persistent scarcity of public resources, the Public-Private Partnership (PPP) constitutes a fundamental tool, capable of bridging the gap between the limited public financial resources available and the need to enhance assets in public real estate $[44,45]$.

In particular, for the enhancement of Palazzo Stella, the PA assumes, according to the hypothesis of enhancement concession, that the recovery and restructuring interventions for new functions of the historic asset are carried out by a private promoter in exchange for the concession temporarily owned for a limited period of time. For the entire period of the concession, the private promoter is responsible for the costs of modernization and all new works deriving from the consequent management. Upon expiry of the concession, the PA returns to the full availability of the property with the acquisition of the property, complete with any transformation and improvement carried out. 
(a)
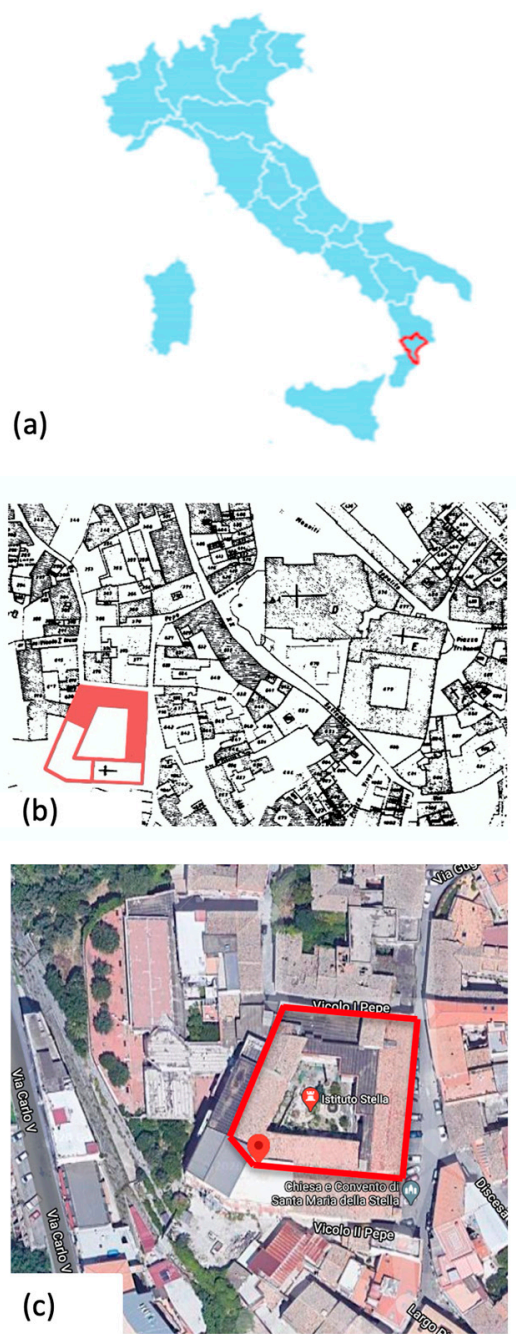

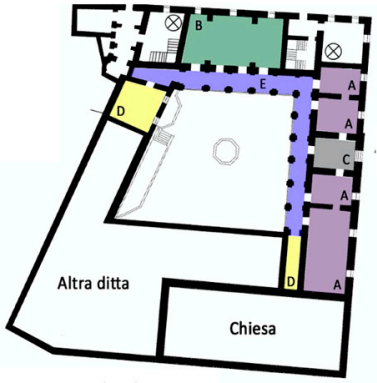

(d) Ground Floor

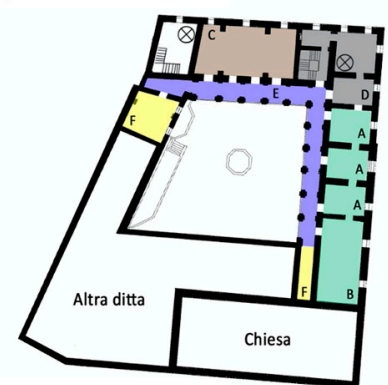

(e) First Floor

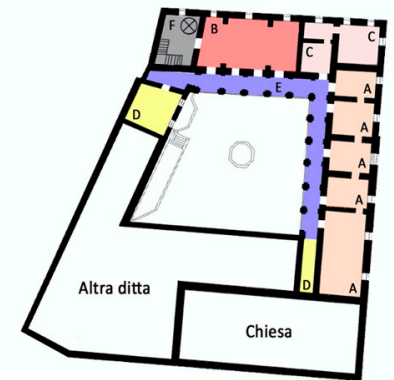

(f) Second Floor

Figure 1. (a-c) location. (d-f) Current functional distribution for each level of Palazzo Stella in Catanzaro (Italy).

\section{Materials and Methods}

\subsection{The Methodological Framework}

The decision-making process associated with the enhancement and adaptive reuse of built heritage is a complicated task, as it involves confrontation with multiple stakeholders and the evaluation of multiple values, which include both tangible (architecture, aesthetic, scientific) and intangible (cultural and social value, etc.) [4].

In such a decision-making context, according to multidimensional criteria both quantitative and qualitative, the approach used in the present research is the classic one proposed by Simon [37] to develop integrated methodologies capable of improving the quality and reliability of decisions, including technical problems related to design projects and cultural, social, and economic, and financial feasibility [29,32,40,46-48].

Moreover, today more than in the past, the scarce availability of public money pushes local governments to evaluate possible investments in advance, while evaluating the feasibility and involvement of private capital in the implementation and management of the intervention. In this scenario, the evaluation can take on a resolute value of existing problems, in the sense that its cognitive apparatus can help build or select implementation strategies of greater effectiveness, efficiency, equity, and social preferability [46].

Concerning to the PPP procedures used in the interventions to enhance public assets, the choice of the new function requires a systematic framework to evaluate the various possible reuse alternatives and sufficient information to identify the best solution, or, in 
any case, the best compromising solution between the objectives of public and private interests [23]. Such a process can certainly contribute to increasing the quality of public decisions [25].

The complexity of the outlined evaluation process underlines the importance of a holistic approach, able to fully consider different perspectives, objectives, stakeholders, values, and mutual benefits [38,39].

In order to meet the needs of the PA, the owner of the property, a methodological framework has been structured that combines, according to a multiphase design, two different methodologies: a multi-criteria analysis and a Discounted Cash Flow Analysis.

Among the mixed evaluation methods [41], the multi-phase approach is particularly appropriate in the context of the outlined study, as it allows to follow the subsequent phases of the evaluation process and have a data set based on the results of the first phase.

The hybrid framework is divided into two phases (Figure 2).

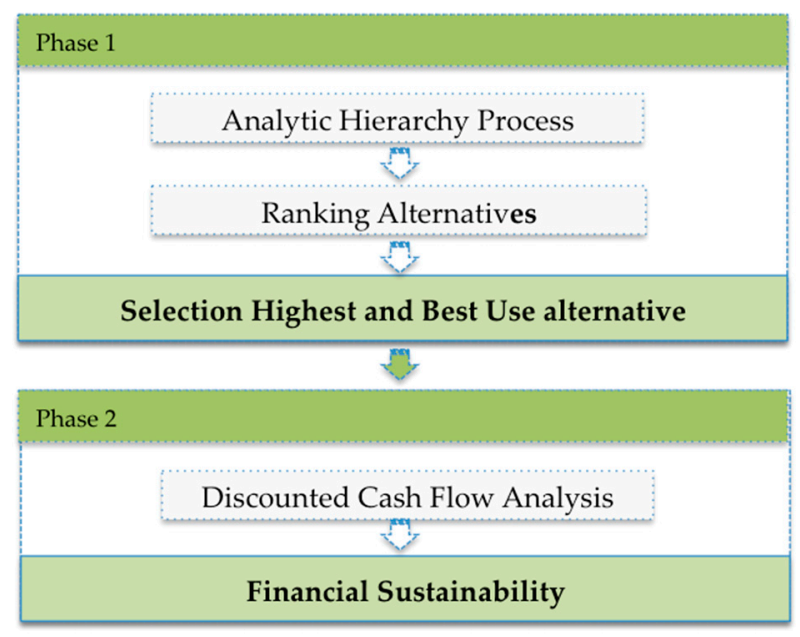

Figure 2. The methodological framework.

In the initial preliminary phase, a rational study approach and a Multi-Criteria Decisional Aid (MCDA) [42,49-60] were used to support the PA in defining the problem, as well as the objectives and values to be achieved to identify the HBU solution $[32,34,40,48]$ among different alternatives for the adaptive reuse of the public good.

In the next phase, on the alternative identified as the HBU solution [34], a Discounted Cash Flow Analysis (DCFA) [43] is developed to validate and verify the feasibility and financial sustainability of the investment in the PPP, as well as the risks of the initiative for the private investor, to whom would be entrusted, through the enhancement concession procedure, the restructuring and management of the asset for an appropriate time to guarantee its financial sustainability.

The enhancement concession is part of the Public-Private Partnership (PPP) procedures [30], characterized by the involvement of private investors in public initiatives [5]. In particular, the concession for the enhancement of public buildings provides that the PA, the owner of the asset, grants private investors the use of public buildings for a certain concession period in exchange for their redevelopment, functional conversion, and ordinary and extraordinary maintenance. Private investors, as managers (and not owners) of the state property, recognize a portion of their revenues to the Public Administration in terms of financial charges (i.e., leases) and/or public works to the local community. At the expiry of the concession period, the PA returns to the availability of the property, with any transformation, improvement, addition, and accession made by the private entrepreneur.

In the redevelopment initiatives of publicly owned assets, as a consequence of the reduction in the spending capacity of the public, it is highlighted that the EC currently represents an effective procedure for the functional conversion of works of collective interest. It is therefore clear that PPP procedures are a valid alternative for financing 
interventions on the territory, capable of giving an immediate response to the contingent needs of modernization and improvement of the country's architectural and cultural heritage $[44,45]$

The development and methodological steps of Phase 1 will not be reported in full. This work, on the other hand, focuses on verifying the financial feasibility of the PPP investment (Phase 2). For the in-depth study and application of the MCDA for the selection of the alternative HBU (Phase 1), please refer to other studies and research applied to historical heritage $[29,32,40,48,61,62]$.

\subsection{Multi-Criteria Decision Aid for Selection of the HBU}

Regarding urban and territorial planning interventions and the building heritage, the Multi-Criteria Analysis (MCA) methodologies make it possible to compare different design solutions based on multiple criteria (economic, social, cultural, and environmental), which can be expressed through both quantitative and qualitative indicators [21,22]. The MCA analysis is, therefore, able to rationalize the process of selecting alternatives through the optimization of a multi-criteria vector, weighted according to the decision maker's priority. In this way, it is possible to include both monetizable and extra-economic criteria, measurable only in physical or qualitative terms, in a single evaluation process [21]. Through logical and mathematical algorithms structured on specific multidimensional parameters, the multi-criteria analysis methods allow the ordering of the possible solutions to the problem, allowing to identify the best compromise solution, evaluated with respect to the set of objectives/criteria [23].

In the preliminary stages of urban investments, the Public Administration has to often deal with complex decisional problems characterized by many variables and conflicting objectives. In these phases, the evaluation is a useful tool that, through the application of MCA, can support the PA in the transformation of a problem characterized by high uncertainty and mostly qualitative judgments of value, in a logical and mathematical model to guide the decisions.

The MCDA methods are widely applied to solve decision-making problems related to all fields of knowledge.

The literature offers a wide range of techniques applied to real cases of reuse that have proved effective in defining an appropriate methodological framework to face the complexity of reuse problems [14-16,24-26,28,37,40,44]. Furthermore, most of the scientific articles belong to the category of alternative use selection/adaptive reuse [48,63-71].

The Analytical Hierarchy Process (AHP) method, developed by Saaty [54-57], is more effective in the presence of the evaluation criteria and sub-criteria, since, through a hierarchical structure at several levels, it allows to break the complex problem into simpler sub-problems that can be analyzed in greater detail and to reach a performing and objective evaluation or decision.

The AHP is the most commonly used method by the PA and private operators to identify the HBU and evaluate the social, cultural, and economic effects [72,73] on the territory of influence [38] of the different alternatives. The reason is the mode in which the complex decision is organized: structuring a decision-making problem as a hierarchy is very natural and easy, as in decision-making, we are trained to break down complex problems into simpler ones.

The AHP method is also advantageous because it is (i) simple in construction; (ii) adaptable to the single individual, as well as to the group of people; (iii) natural to our intuition and general thinking; (iv) encourages compromise and consensus building; (v) an easy methodology that does not require a particular specialization; (vi) easily communicable; (vii) associates the inductive and systematic approach with the deductive approach, two methods used by man to solve problems; (viii) judgments expressed through comparison in pairs are more robust; and (ix) it allows one to easily review the entire decision-making process $[32,33,38,72,73]$. 
The AHP method is so-called because it is a process of analytical hierarchy, in which the complex decision problem is divided into fundamental analytical elements [56,57], which constitute the factors that influence the final decision. It is at the same time a hierarchical process, because the decomposition of the problem occurs at successive levels with ever-increasing detail [52].

The use of the hierarchical diagram, the matrix of criteria, and the matrices of the alternatives in the input phase, as well as the effective graphic representation of the results in the output phase, connote the multi-criteria technique of simplicity and operational clarity of the process that is logical and mathematical for all those involved. The availability of open-source software and the possibility of reproducing the model through simple spreadsheets (as in the procedure adopted in this work) makes the application of this tool particularly easy to understand, even by less experienced users.

The high transparency of the AHP and the simplicity of the representation of the different phases constitute the etiology of the widespread application of this multi-criteria technique and its intrinsic effectiveness in identifying shared choices [72-75].

For all of the reasons listed above, the AHP is the most applied method, particularly in the field of cultural heritage, and for this reason, it was used for the case study of Palazzo Stella to identify HBU among some reuse alternatives identified.

For application to the case study, once the objective of the PA was defined, the AHP method proved to be particularly effective in the evaluation context outlined. Once the objective is established, the HBU for Palazzo Stella, the AHP method is particularly useful in evaluating the identified design alternatives through a variety of independent, often antithetical, objectives/criteria related to financial as well as social, cultural, and environmental issues.

From a procedural point of view, this approach consists of three steps: (i) construct suitable hierarchies; (ii) establish priorities between the elements of the hierarchies through pairwise comparisons; and (iii) check logical consistency of pairwise comparisons [54-57].

The first step concerns the construction of suitable hierarchies. The simplest model of the hierarchy consists of three steps. The first step coincides with the main objective (called the goal) of the decision-maker; the second and third steps include criteria and alternatives. It is, however, possible to develop more complex hierarchies (i.e., with more levels), which include a certain number of sub-criteria. This means that factors affecting the decision are organized in gradual steps from the general, in the upper level of the hierarchy, to the particular in the lower levels. The second step establishes priorities between elements of the hierarchies, employing pairwise comparisons (i.e., comparing elements in pairs concerning a given criterion) with respect to the corresponding elements in the next higher level and obtaining a matrix of pairwise comparisons. For representing the relative importance of one element over another, a suitable evaluation scale is introduced [76,77], Saaty's scale, that defines and explains the values 1 to 9 assigned to judgments in comparing pairs of elements in each level to a criterion in the next higher level [54,55]. In particular, for each criterion $C$, an n-by-n matrix A of pairwise comparisons is constructed. The components $\mathrm{a}_{\mathrm{ij}}(\mathrm{i}, \mathrm{j}=1,2, \ldots, \mathrm{n})$ of the matrix A are numerical entries, which express (employing Saaty's scale) the relative importance of the element $i$ over the element $j$ with respect to the corresponding element in the next higher level. Thus the matrix A has the form:

$$
\mathrm{A}=\left[\begin{array}{cccc}
a_{11} & a_{12} & \cdots & a_{1 m} \\
a_{21} & a_{22} & \cdots & a_{2 m} \\
\vdots & \vdots & \ddots & \vdots \\
a_{n 1} & a_{n 2} & \cdots & a_{n m}
\end{array}\right]
$$

where $\mathrm{a}_{\mathrm{ii}}=1 \cdot \mathrm{a}_{\mathrm{ji}}=1 / \mathrm{a}_{\mathrm{ij}}, \mathrm{a}_{\mathrm{ij}} \neq 0$.

To calculate relative priorities among the n elements considered, the principal eigenvector of matrix $A$ is computed. Then, this eigenvector is normalized, obtaining the priority vector, which expresses the priorities among the elements belonging to the same node of 
the hierarchy. Each component of the vector $x$ represents the local priority of an element (i.e., a node of the hierarchy) of the pairwise comparisons; the global priority of that element is the product of its local priority with the global priority of the upper node.

In comparing elements, the inconsistency of a certain degree can arise: in the AHP approach, the maximum or principal eigenvalue (called $\lambda_{\max }$ ) of each matrix of pairwise comparisons is computed for checking the degree of inconsistency.

Saaty proposes a consistency ratio to appreciate the consistency of the matrix. A consistency ratio of 0.10 or less is considered acceptable; if this ratio is more than 0.10 , it is necessary to reformulate the judgments using new pairwise comparisons $[55,56]$.

In real applications, the ease of use of the AHP is highlighted, as well as its robustness, confirmed by the consistency analysis, and the transparency of the procedure, without "black boxes" [78].

In the AHP, the alternatives are usually identified during a focus group organized by the promoter with the expert (architect, economist, and sociologist) and politicians. The alternatives are evaluated considering a technical evaluation linked to the preferences of the DM and a political-social evaluation linked to the points of view of the parties involved, expressed through scores/weights [31,32]. The technical evaluation makes it possible to define a ranking of alternatives based on the criteria [40-43].

The choice of criteria and any sub-criteria is fundamental for the correct application of the AHP method. The evaluation criteria and sub-criteria are chosen based on the literature of the sector [79] or even in a focus group with the PA, experts, and technicians of the sector. The criteria chosen must be multidimensional in nature precisely to evaluate alternatives on a multidimensional scale, and must consider antithetical aspects that are social, cultural, historical, and economic in nature [14-16,24,28,31-34,37].

The AHP method can take into account the interdependence existing between the different evaluation criteria through the construction of suitable hierarchies $[3,24,28]$. The elements of a hierarchy (i.e., criteria, sub-criteria, alternatives) are not linked to all of the others, but they are grouped into disjointed sets; if an interdependence between some elements is recognized, they are placed in the same hierarchical level and connected to the same element of the next higher level. If the choice of the number of hierarchical levels is unlimited (although, as a rule of thumb, no more than seven elements for each node is best), it is possible to insert in the hierarchy all of the criteria required by the decision-making problem. In this sense, a complete (i.e., exhaustive) list of independent assessment criteria is allowed.

\subsection{Financial Feasibility in $P P P$}

In recent decades, there has been a progressive change in the management of public real estate: the need to restore public finances has led governments to favor their concession to private individuals, intending to transform real estate from cost to resource financially. The progressive involvement of the private investor in the redevelopment initiatives of publicly owned assets highlights how this form of collaboration currently represents an effective procedure for the functional conversion of works of collective interest, to be tested with new forms of cultural enterprise and active citizenship, as well as governance models shared with local for-profit/non-profit organizations [80-82].

The evaluation of the system of conveniences presupposes the definition of the role assumed by each actor involved in the process of enhancing the public good. For the public administration, the PPP is a fundamental tool, capable of bridging the gap between the limited public financial resources available and the need to enhance its real estate assets [83-85]. The advantages deriving from the concession of one's own assets are mainly of two types: freeing oneself from onerous loads, in terms of management and protection, and having new financial resources to reinvest for the enhancement of the remaining part of the public assets [43,86].

For the private investor, participation with one's own capital in these initiatives presupposes the fulfillment of the criterion of financial convenience of the operation, or the 
ability of the intervention to remunerate the capital initially invested and to generate an adequate profit for the private operator: the entrepreneur will invest his own capital, assuming the risks of the initiative, where assessment of the feasibility of the intervention certifies that the revenues will be greater than the transformation and management costs [87-91].

In Italy, within the wide range of PPP operational tools, the enhancement concession allows the reactivation of public real estate assets through the assignment to private operators of the right to use the properties for a specific period of time, against their requalification, functional reconversion, and ordinary and extraordinary maintenance $[46,92]$.

Due to the numerous positive impacts that these methods of managing public buildings can generate at the local and supra-local level, the hypothesis assumed in this work is that the current owner of the disused property chooses, within the range of PPP operational tools, the enhancement concession procedure for the enhancement of the asset and the start of an adaptive reuse process. In particular, it is assumed that the restructuring operations are carried out by a private promoter (principal entity) in exchange for the concession of temporary use of the property, lasting 30 years [93]. Upon expiry of the concession, the public entity is fully available to the property, with the acquisition of any transformation and improvement made to it [45-86].

The investment decisions by a private developer in a given real estate project, and therefore its feasibility, depend on the results of the economic and financial forecasts and on the profitability expectations associated with the investment itself. The technique most often used to carry out preventive economic assessments is based on Discounted Cash Flows (DCFA) [46].

The criterion on which the estimate of the profitability of the DCFA analysis is based in the discounting, i.e., on the determination of a present value and of the flows (revenues minus costs) generated by the investment [92].

In the DCFA analysis, cash flows are represented by the difference in each time period between revenues due to sales or services and costs. This increase in wealth, assessed at the initial moment that the operator achieves thanks to the investment, is defined as the Net Present Value (NPV), is the first indicator of the profitability of the operation, and represents, as shown in Equation (1), the discounted sum of the cash flows (F) at time $t$ (with $\mathrm{t}$ variable from 1 to $\mathrm{n}$ ), with $\mathrm{r}$ being the rate of interest.

$$
N P V=F_{1} /(1+r)+F_{2} /(1+r)^{2}+\ldots+F_{n} /(1+r)^{n}=\sum_{t=1}^{n} F_{t} /(1+r)^{n}
$$

In the literature, there are numerous applications of the DCFA for preventive economic evaluations in real estate investments, relating both to urban regeneration projects [43-45] and to the valorization of cultural heritage $[44,45,48]$.

The financial feasibility check of the PPP initiative was carried out using the enhancement concession procedure.

The application to the case study allows to reconcile the multiplicity of subjects involved in urban regeneration initiatives through PPP procedures, and to delineate the consequent cascade system [86].

The evaluation of the mutual advantages for the parties involved in the concession procedure presupposes the clarification of the roles assumed by each of the parties in the investment: the public administration and private investors [30,44,86].

Once the roles assumed by each of the parties involved in the initiative were defined, the costs (investment and management) and the related revenue items were identified, which define the economic items of an updated cash flow analysis. The financial assessment of the transaction was then carried out, determining the related performance indicators [32-80] to assess the financial sustainability of the entire transaction. 


\section{Application and Results}

\subsection{AHP Implementation}

In the first phase of the framework, the multi-criteria methodology AHP was applied to choose the highest and best reuse for the Palazzo Stella from a historical, architectural, cultural, social, and financial point of view, to obtain social, cultural, and economic benefits from its enhancement and reuses. The implementation of the AHP method required a preliminary historical, architectural, and technological analysis of the property, subject to evaluation.

The method was structured to mutually compare multiple alternatives based on both financial and non-financial criteria.

The selection of the alternatives, which occupied the last level of the hierarchy, derived from a careful analysis of the needs of the community and of the socioeconomic and demographic characteristics of the reference territory. They were identified and selected within a focus group organized by the PA—the promoter of the project-with experts in the fields of architecture, economics, and sociology, as well as citizens, associations, and political representatives of the PA:

(i) A1. Tasting center of food and wine itineraries and cooking workshops, with an adjacent museum of local crafts. In essence, it proposes a hub of food and wine culture linked to local places and experiential tourism activities linked to food: gastronomic festivals, food fairs, events, cooking shows, tastings of typical products, and gastronomic itineraries;

(ii) A2. Social and healthcare residences for non-self-sufficient elderly people (60 beds). The residential center offers physical rehabilitation programs and health services to protect the health and well-being of the elderly, maintain and strengthen their residual capacities, stimulate an active social life, and provide concrete support to families;

(iii) A3. Multifunctional rooms for conferences, seminars, thematic meetings, exhibitions, and multimedia seminars. This reuse alternative includes multifunctional rooms, coworking spaces, and finely equipped and functional environments for events, business meetings, or interviews, with rooms intended for teaching activities, professional meetings, laboratories, and workshops, and a break area equipped with a professional kitchen. The privileged target are freelancers, cultural startups, and social promotion associations operating in the third sector;

(iv) A4. Residence with annexed services and a wellness center. The idea is to offer a multisensory journey totally focused on relaxation and well-being. Inside the historic building, areas dedicated to relaxation will be available: a Finnish sauna, Turkish bath, sensory showers, Kneipp path, relaxation area with herbal tea and fresh fruit, swimming pools with hydro-massage and counter-current swimming, and a wide choice of Western and Eastern massages.

To compare the alternatives described, the decision problem was structured according to a hierarchical scheme that distinguishes objectives, criteria, and sub-criteria. The objective was represented by the highest and best reuse for Palazzo Stella, intended as adaptive reuse capable of generating the best results in terms of social, cultural and financial repercussions. Obviously, all of the alternatives were assessed technically, and were considered feasible from an urban planning point of view.

The criteria and sub-criteria represented a fundamental variable in the multi-criteria evaluation and the application of the AHP method [32,34,70,94-98].

The judgment for each alternative was expressed after a thorough analysis of the criteria. For all hypotheses of reuse, numerical values were assigned to the indicators representative of the criteria and sub-criteria.

In the application of the AHP, three were first-level criteria and nine were second-level sub-criteria.

The first level criteria, against which the four alternatives are compared, were: 
- Social value (S). The ability of the project to respond to social needs is understood as an expression of the needs of the current, potential, and future community. This criterion includes the following two sub-criteria:

- (S1) Community involvement, understood as the average number of daily users who frequent the facility, measured by the structure's maximum capacity index;

- (S2) New job opportunities activated by the new function, measured as the number of potential new permanent workers hired to manage the structure.

- Historical and Cultural value $(\mathrm{CH})$. It represents the "intrinsic value of the historical good" represented by the values of an immeasurable and qualitative nature. It includes the following sub-criteria:

- $\quad(\mathrm{CH} 1)$ Cultural effects, attractiveness concerning to cultural events; this is expressed as the ratio between the surface used for cultural activities $\left(\mathrm{S}_{\mathrm{C}}\right)$ and the total area of the building $\left(\mathrm{S}_{\mathrm{T}}\right)$;

- $\quad(\mathrm{CH} 2)$ Compatibility of the function with the historical and architectural characteristics of the building. This criterion depends on the three sub-criteria:

- $\quad(\mathrm{CH} 3)$ Representativeness of the use function, the aptitude to enhance the cultural peculiarities of the territory, and respecting the material and spiritual reality of the architectural asset, rated on a scale of 1 to 7 ;

- $\quad(\mathrm{CH} 4)$ User impact, the average number of daily users: the higher this number, the lower the score attributed to the alternative. To protect the cultural asset, functional activities with a moderate impact are preferable in order to avoid excessive loads on the structure, which may require static adaptation interventions, such as compromising the historical authenticity of the asset; this criterion is evaluated according to the S1 criterion;

- $\quad(\mathrm{CH} 5)$ Minimal intervention, preservation of the characteristics of the building, in order to avoid invasive interventions that could reduce the artistic and monumental quality of the property. This criterion represents one of the principles of the architectural restoration and conservation of historic buildings. It is, therefore, a qualitative value rather than a quantitative criterion; the judgment was assigned by the decision-makers, according to a qualitative scale from 1-7.

- Economic and Financial value (EF). Monetary benefits that the resource achieves in terms of cost opportunity and economic development. This criterion includes the following three sub-criteria:

- (EF1) Existence/absence of competitors of similar activities in the municipality: yes/no;

- (EF2) Investment costs: $€ / \mathrm{m}^{2}$;

- $\quad$ (EF3) Return on investment (ROI) for the private entity. This value is derived from information on the profitability of a similar economic sector of reference in the survey area.

The sub-criteria illustrated above are placed at the second level of the hierarchy and evaluated considering the relatively higher level criterion, from time to time, according to the three aspects of the economic, social, and cultural values, explained at the upper level.

\subsection{AHP Results: Selection of the Highest and Best Reuse of a Historic Building}

Once the alternatives, evaluation criteria, and sub-criteria were defined and the hierarchical decision-making model was outlined, the scaled decision matrix AHP was implemented (see Table 1). In this matrix, the generic element $\mathrm{a}_{\mathrm{ij}}$ (attribute) expressed the performance of the generic alternative $\mathrm{Ai}(\mathrm{i}=1,2, \ldots, \mathrm{n})$ with respect to the generic criterion Cj $(j=1,2, \ldots, m)[54-57,70]$ 
Table 1. The AHP scaled decision matrix.

\begin{tabular}{|c|c|c|c|c|c|c|c|c|c|}
\hline & S1 & $\mathrm{S} 2$ & CH1 & $\mathrm{CH} 3$ & $\mathrm{CH} 4$ & CH5 & EF1 & EF2 & EF3 \\
\hline Alternatives & $\begin{array}{l}\text { Community } \\
\text { Involvement } \\
\text { (n. Users) }\end{array}$ & $\begin{array}{c}\text { New Job } \\
\text { (n. Workers) }\end{array}$ & $\begin{array}{l}\text { Cultural } \\
\text { Effects } \\
\left(\mathrm{m}^{2} / \mathrm{m}^{2}\right)\end{array}$ & $\begin{array}{l}\text { Represent. } \\
\text { Function } \\
\text { (Scale 1-7) }\end{array}$ & $\begin{array}{l}\text { User Impact } \\
\text { (n. Users) }\end{array}$ & $\begin{array}{c}\text { Minimal } \\
\text { Intervention } \\
\text { (Scale 1-7) }\end{array}$ & $\begin{array}{c}\text { Existence } \\
\text { Competitors } \\
\text { (Yes/No) }\end{array}$ & $\begin{array}{c}\text { Investment } \\
\text { Costs } \\
\left(€ / \mathrm{m}^{2}\right)\end{array}$ & $\begin{array}{l}\text { ROI } \\
(€ / €)\end{array}$ \\
\hline $\mathrm{A} 1$ & 124 & 15 & 0.34 & 5 & 124 & 3 & no & 320 & 0.042 \\
\hline A2 & 156 & 23 & 0.63 & 6 & 156 & 6 & no & 370 & 0.013 \\
\hline $\mathrm{A} 3$ & 165 & 16 & 0.66 & 6 & 165 & 5 & yes & 460 & 0.071 \\
\hline A4 & 140 & 16 & 0.21 & 3 & 140 & 4 & yes & 580 & 0.101 \\
\hline
\end{tabular}

In the development of the AHP in the case study, the pairwise comparison matrices and the pairwise normalized comparison matrices were elaborated on by implementing Microsoft Excel software and obtaining the score of each alternative for each criterion and sub-criterion.

Calculating the total scores of the alternatives, the ranking showed alternatives A2 and A4 in the first place (see Table 2), with equal merit in the neutral scenario, in which all criteria have the same weight/importance:

- $\quad$ A2. Social and healthcare residences $(\mathrm{TS}=0.33$ );

- A4. Residences with annexed services and wellness center $(\mathrm{TS}=0.33$ );

- A3. Multifunctional rooms for conferences (TS $=0.26$ );

- $\quad$ A1. Tasting center of food and wine itineraries $(T S=0.08)$.

Table 2. The AHP: ranking alternatives.

\begin{tabular}{lcccc}
\hline & \multicolumn{4}{c}{ Alternative } \\
\hline Scenario & A1 & A2 & A3 & A4 \\
\hline S1. Neutral & 0.08 & 0.33 & 0.26 & 0.33 \\
S2. Social-Hist-Cultural & 0.08 & 0.40 & 0.24 & 0.28 \\
S3. Economic-Financial & 0.09 & 0.26 & 0.26 & 0.39 \\
\hline
\end{tabular}

To assess the robustness of the results, the evaluation was also conducted regarding two other scenarios, obtained by varying the weights of the criteria:

- in scenario S2: social, historical, and cultural criteria prevail over economic criteria;

- in scenario S3: economic criteria prevail over socio-cultural criteria.

The AHP methodology implemented according to the two scenarios S2 and S3 showed for scenario S2 the alternative A2 in the first place (0.40), followed by A4 (0.28), A3 (0.24), and (0.08), while, for the S3 scenario, the ranking showed A4 (0.39) in the lead, followed by A2 (0.26), tied with A3 (0.26), and finally A1 (0.09).

The complete ranking for the three scenarios is shown in Table 2.

The ranking and comparison between the three scenarios highlighted the A2 alternative as the best compromise solution between all alternatives. Only for scenario 3 was alternative $\mathrm{A} 2$ positioned in second place after A4, for more than positive cash flows, even if slightly lower than alternative A4, which, however, scored lower both on social and historical and cultural criteria.

The alternative A2. Social and health residences are therefore definitively chosen by the PA as the highest and best reuse alternative for the enhancement of Palazzo Stella, for the positive impacts on all criteria. In particular, the A2 alternative generates very positive impacts both on a social level, in terms of community involvement and new stable jobs, and on a historical and cultural level for the involvement of the cultural associations in the activities involving the reuse of the property, but, above all, for the minimum interventions on the structure. 


\subsection{Result DCFA: Evaluation of the Financial Feasibility of the A2 Reuse Alternative}

The objective of the economic and financial plan in this second phase is to evaluate the financial sustainability of the Residence Social Assistance (RSA) by the private investor. In practice, it is necessary to verify whether the investment for recovery and redevelopment will be repaid through the management of the structure in the new and better configuration A2. Social and healthcare residences for non-self-sufficient elderly people -60 beds $[30,44,92]$ as the highest and best reuse destination, chosen through the AHP multi-criteria process previously described.

The verification of the financial sustainability of an initiative for the enhancement of a public property carried out through a PPP procedure (in individual or corporate form), is carried out through the development of a Discounted Cash Flow Analysis (DCFA). The feasibility conditions of the project are verified in terms of the Net Present Value (NPV), the Weighted Average Cost of Capital (WACC), Debt Service Cover Ratio (DSCR), and Loan Life Cover Ratio (LLCR) [46,92]. The willingness of the private subject accepting the cooperation mechanism with the Public Administration is based on the private convenience of the intervention and, therefore, on the ability of the initiative to repay the initial monetary outlay, to remunerate the management, and generate a financial surplus.

\subsubsection{Costs Estimate of the Initial Investment} Initial Investment

The costs of the initiative concern: (i) the investment for the renovation and arrangement of the property and the outdoor area, and (ii) the direct and indirect management for the intended uses leased to third parties.

This cost item is obtained from the project's Technical Economic Framework (TEF) [99] and includes the amount relating to the construction and plant engineering works, the arrangement of the outdoor uncovered area, and the amount of technical and general expenses, determined to an extent percentage equal to $6 \%$ and $3 \%$ of the construction cost, respectively, in addition to the sums necessary for the purchase of the furnishings.

The summary measure of construction costs was taken from the lists of public and private works currently in force in the Calabria Region and validated through formal investigations conducted at construction companies operating in the Province of Reggio Calabria.

The investment paid by the private operator is therefore equal to $€ 1.8$ million.

\section{Future Investment}

The plan also assumes (on a ten-year basis) future interventions, such as extraordinary maintenance and replacement of parts of the furnishings.

For extraordinary maintenance, the estimated amount (equal to $3 \%$ of the overall value of the structure, approximately $€ 3.3$ million) is approximately $€ 100,000$; regarding the furnishings, however, it is assumed that the dealer needs to change only one-third of the furniture every ten years, equal to about $€ 110,000$. In both cases, the values refer to the moment of the estimate and are included in the plan increased for each year based on the inflation forecasts.

\section{Management Costs}

The overall management costs framework, calculated based on a period of activity of the established functions equal to 365 days/year, includes the costs for healthcare and nursing staff; expenses for other staff; hotel costs for users; general operating expenses; expenses for staff training courses; ordinary maintenance costs; and the annual rent for the property for the lease of the respective surfaces.

The estimate of the healthcare and nursing staff refers to the regional regulatory requirements and starts from the detail of the staff managed by the concessionaire, divided by qualification and specific skills, with an indication of each minimum service to be provided according to the number of users hosted in the facility (minutes for users). 
Per regional regulations, a health director must be present, here considered part-time, because the hospital is characterized by several beds (less than 120); also, the manager of the structure can be, for similar reasons, associated with other Social and Health Care Residences (SHCR), and therefore carry out part-time activities. The professional figures that provide strictly medical services (general practitioners and specialist medicine) have not been included in the staff managed by the concessionaire, as they are the responsibility of the National Health Service, as well as the staff for psychological support to users.

The nursing and personal protection fees have been sized according to the minimum benefits to be provided to users of the facility.

The costs for healthcare and nursing staff were therefore determined based on these organizational hypotheses, and based on the average gross wages derived for each professional figure from the respective national employment contracts. The costs for personal protection assistance were instead estimated at $75 \%$ of the costs of the nursing staff. Lastly, the performance of the animation activity was considered among the tasks of the Home Assistance and Guardianship Services (HAGS) staff, the Technical Assistance Operator (TAO), and the Healthcare Worker (HW) staff, assisted by volunteers whose profiles are defined by the reference regulations. The total annual cost is $€ 470,000$. Regarding the other structure personnel, it was decided to consider the coverage of three functions as the administration, the secretariat, and the concierge. Still, regarding regional regulations, the concessionaire is also required to provide users with a basic hairdressing service, as regards the minimum activities related to personal hygiene. The total annual cost is $€ 75,000$.

In estimating the hotel costs for RSA users, daily meals were identified (calculated in days of food, taking into consideration that the dealer decides not to produce meals directly in the structure due to the lack of adequate spaces), the laundry (which includes cleaning and flat linen, both strictly personal), and the cleaning of the structure. The total cost is $€ 430,000$.

The annual heating costs, the costs for drinking water, the supply and consumption of electricity, telephone costs, and costs for insurance and miscellaneous expenses were also estimated in the operating costs. As the regional legislation provides that the manager is also responsible for training the employees, two mini-courses of professional updating of 20 hours/year have been hypothesized during the duration of the concession. The total annual cost is $€ 100,000$. The ordinary maintenance cost was estimated at $0.50 \%$ of the structure value at the end of the works; this expenditure, as well as the other costs considered so far, also increases every year with inflation. The total annual cost is $€ 16,500$.

\subsubsection{Revenue Estimate}

To estimate revenues, it is necessary to establish the type of assistance provided; with a view to greater flexibility, it was decided to consider an equitable division of patients into the three social healthcare categories (high, medium, and low).

As a precaution, the plan provides coverage of $90 \%$ of the available places ( 54 users against the 60 available beds) equally divided, as mentioned, among the three levels of social and health services. Finally, it was assumed that the places occupied were 100\% under an agreement with the Calabria Region and with the Local Health Authority of reference. Therefore, the indications referred to in the regional regulations were used to define the unit tariffs. Total annual revenues are $€ 1,650,000$. The plan then prefigures an update of tariffs every six years, equal to $100 \%$ of the increase suffered by costs due to inflation (estimated at $2 \%$ per year).

\subsubsection{Building the Financial Plan}

In terms of duration, a 30-year concession was assumed, in addition to the year necessary for the implementation of the initial recovery and requalification.

Regarding the financial structure of the investment, it was estimated that the mix of financial resources most suitable for financing the entire structure was made up of $30 \%$ risk capital (financing supported by the concessionaire) and 70\% debt capital (financing 
sustained by taking out a loan from a credit institution). The duration of the loan for the initial capital loan has been assumed to be 30 years, which is the entire duration of the management concession. To deal with subsequent investments (extraordinary maintenance and replacement of furnishings) the dealer contracts new mortgages of twenty and ten year durations. The applicator interest rate is equal to $4.75 \%$, inclusive of spread.

The amortization of the initial building investment was distributed over 30 years, with an annual rate of $3.33 \%$; as said, $70 \%$ of the furnishings purchased with the initial investment are assumed to have low technical and functional obsolescence, that is, the dealer is not forced to bear additional costs for their replacement during the duration of the concession. These purchases are in any case amortized over 10 years, taking into account the maximum percentage shares prescribed by the reference ministerial tables. The remaining $30 \%$ of the new acquisition, on the other hand, behaves according to an average level of obsolescence (the useful life of 10 years). From the tenth year onwards, the additional rate calculated among depreciation relates to investments for extraordinary maintenance.

The direct taxes considered are the corporate income tax and production tax. For indirect taxation, the recovery of VAT was assumed referring to the initial investment and costs incurred during the duration of the concession.

\subsubsection{Evaluation of the Results}

In terms of duration, a 30-year concession was assumed, in addition to the year necessary for the implementation of the initial intervention.

Against an initial investment by the dealer of $€ 1.8$ million (of which only $30 \%$ is of equity capital and the remaining $70 \%$ of loan capital), the cash flows developed in the following 30 years (management phase) lead to a positive NPV. The economic convenience of the project or the ability of the intervention to create value and generate a level of profitability for the invested capital, adequate to the expectations of the private investor, is confirmed by the result of the indicators considered: the project, based on the assumptions made, can cover the investment and management, with an NPV higher than $€ 742,000$ (covers the invested equity capital) and a WACC equal to 8.04\% (weighted average of the expected return on capital).

Financial sustainability, expressed in terms of bankability, or the ability of the project to generate sufficient cash flows to guarantee the repayment of the loans activated, was analyzed through two main coverage coefficients: the DSCR and LLCR. In this specific case, both indices took values far greater than unity (see Appendix A).

\section{Discussion}

Through the case study, it was possible to prepare an integrated assessment framework to support the PA in choosing the HBU of Palazzo Stella. The flexible and adaptive decision-making process was capable of taking into account the complexity of the decision-making process, the value of the cultural heritage under consideration, and the multiplicity of actors involved in the decision-making process. A2: Social and healthcare residences is the preferred functional solution regarding the objective of the highest and best reuse and the selected evaluation criteria. Furthermore, this alternative achieves the highest level of consensus among the stakeholders involved in the decision-making process [32-34,40,48,61-68].

The final assessment, relating to the final assessment of financial sustainability, confirms the ability of the A2 alternative to create value and generate a level of return on invested capital, adequate to the expectations of the private investor.

The experimentation, applied to the case study, showed that the combination between MCDA and DCFA can be a useful tool to support the local government in the decisionmaking process - characterized by different elements of complexity - that involves more rigorous, transparent, and effective planning of interventions on built heritage and in environments characterized by high complexity, such as cultural heritage, oriented to (i) predict the effects and impacts of enhancement projects; (ii) choose the highest and best 
alternative reuse functions for the enhancement of assets from a sustainable perspective; (iii) select the functional model achievable through the use of private capital; and (iv) assess the convenience of the investment through the ex-ante assessment of financial sustainability for the private entity.

Today, the new challenge for local administrations is to regenerate the abandoned building heritage by involving different stakeholders and the local community to create new governance models capable of guaranteeing the enhancement of historical heritage and cultural values, as in the case study, which represents a symbolic building for the community and strategic investment for sustainable urban development. In this perspective, future research in this field is oriented, according to the concept of "heritage as commons", to prefigure sustainable experiments for the management of common goods to support the decisions of the PA.

\section{Conclusions}

The theme of the reuse of historic buildings is highly topical because it reflects the huge number of abandoned or underused buildings that can become a driving force for urban regeneration and for pursuing sustainable urban development. At the same time, there are numerous impacts to consider, from a financial, social, cultural, and environmental point of view. Therefore, at the methodological level, this issue requires the use of techniques of economic evaluation to direct the decision-maker towards optimal solutions in the allocation of public resources, and the identification of the Highest and Best Use $[28,60,64,77,94]$ from an operational point of view.

Necessarily, the choice of the function for historical and architectural assets of value must derive from a multidisciplinary study based on multiple criteria and sub-criteria of estimation and a plurality of parameters of a different nature, useful for expressing the interests - financial and otherwise - of both individuals who are part of the community involved, without neglecting the protection of the historical and architectural characteristics of the cultural heritage, according to the restoration approaches [70].

The construction of a cognitive in-depth framework of the asset, in fact, leads to information and data that can help in the choice of the optimal function, compatible from the historical, cultural, architectural, structural, and urbanistic point of view, supported by effective choices in terms of maintenance, enhancement, and future investments.

Many experiments show that the Public Administration, which is characterized by the availability of a priceless cultural heritage, does not have the sufficient economic and managerial capacity necessary to keep its assets efficient over time. This pushes local administrators to evaluate possible investments in advance and see in the private interlocutor (for-profit or non-profit) the key actor with whom to collaborate and cooperate to promote projects to enhance their assets, aimed at and supporting entrepreneurship and employment, by supporting innovative forms of business capable of triggering economic development processes, and of raising the quality of the cultural offer, both local and national $[6,22,30,43,89]$.

In this context, through the implementation of the multi-methodological model, this work outlines an innovative economic evaluation protocol based on (a) the preliminary selection of possible functional destinations among those technically feasible, urbanistically admissible, economically convenient, and historically valid; (b) the use of an evaluation procedure and a careful selection of evaluation criteria and sub-criteria, with a final ranking of alternatives that identifies the Highest and Best Use solution [34,78] for the historical heritage; and (c) a DCFA model to support the verification of the financial feasibility of the investment in PPP $[6,27,30,33,44,48]$.

In these circumstances, the evaluation of alternative scenarios is, therefore, a complex decision-making problem in which it is necessary to consider several aspects simultaneously, taking into account both technical elements, which are based on empirical observations, and non-technical elements, which are based on social views, preferences, and feelings. 
In this research, what we have tried to set up and experience in the field is a hybrid approach, a two-phase methodology, based on multidisciplinary work, chosen to support decision-making processes in the context of urban design and project evaluation [41].

The approach proposed in this work has an innovative character, because it considers the integration of different methods to support the entire process and their first preventive application in the investment planning phase, from the definition of objectives and values to be achieved with the intervention up to the verification of the convenience and economic and financial sustainability. To the knowledge of the authors of this article, this study represents the first experimentation of the combination of a specific MCA technique (AHP) with DCFA analysis.

The multi-phase hybrid model has proved to be an effective decision support tool, guaranteeing both public administrations and private individuals an optimal allocation of available resources, with obvious and important implications for urban regeneration and sustainable economic development.

The application developed in the case study confirmed the advantages of a multimethodological evaluation process to support the whole decision-making process, characterized by numerous elements of complexity (from the problem definition phase to the evaluation of the feasibility and economic and financial sustainability of the HBU function selected), able to incorporate the opinions of the different points of view and experts involved in the decision-making process [37].

Within the initial evaluation process, the use of multi-criteria methods allows the building of a methodological framework aimed at selecting among different hypotheses of reuse the HBU alternative for which there is greater economic and social convenience for the community, and which achieves the maximum consensus among all interested parties involved in the decision-making process [32-34].

Through the economic and financial plan, it has been possible to verify the economic and financial convenience and the involvement of private capital for the implementation of the interventions and management of the intervention, that is, if the investment sustained by the private entity for the recovery and redevelopment will be repaid through the management of the structure in the new and best configuration and destination of use selected, chosen as the HBU destination through the AHP multi-criteria method described.

In particular, the results relating to the economic and financial verification show that, for the identified reuse scenario, the PPP management model chosen is feasible as well as sustainable in the long-term from an economic point of view, as the revenues from management allow full coverage of operating costs, including ordinary and extraordinary maintenance, without additional charges and costs for the public sector $[30,44]$.

Ultimately, the analysis conducted highlights the significant support that can derive from the preventive assessment in the initial stages of defining investment in PPP to enhance the public cultural heritage. The identification of the various figures involved in the initiative allows one to make explicit, systematize, and clarify the roles of each operator, the related costs to be incurred, and the returns to be collected [100].

The implementation of a DCFA and the evaluation of the performance indicators made it possible to verify the ability of the operation to adequately offset the risks of the initiative for the promoting investor. The choice of the functions envisaged in the new real estate complex and the different management methods (direct and indirect) made it possible, on the one hand, to satisfy the requirement of financial convenience for the investor, and on the other, to transfer a large part of the risks of the real estate investment to the various stakeholders and, for each market sector, the most competent.

The multi-methodological model has proven to be effective decision support both for the PA and for the private bodies interested in the recovery and management of the asset. In the process that guided the choice of the HBU among some hypotheses of reuse, various multidimensional objectives are pursued, in addition to the verification of the sustainability and financial feasibility of the functions planned over time, without any burden for the 
community and with positive effects on economic policy, deriving from the enhancement of a building characterized by numerous elements of complexity.

Today, the new challenge for the PA is to regenerate the abandoned heritage by involving the various stakeholders, the local community, and investors to create new management models capable of guaranteeing the conservation of cultural values and, at the same time, through enhancement interventions, ensuring their economic sustainability over time.

Funding: This research received no external funding.

Institutional Review Board Statement: Not applicable.

Informed Consent Statement: Not applicable.

Data Availability Statement: The data presented in this study are available on requesting from the corresponding author.

Conflicts of Interest: The author declares no conflict of interest. 


\section{Appendix A. Result DCFA. Evaluation of the Financial Feasibility of the Investment}

Table A1. Feasibility and financial convenience of the management model in PPP of the A2 reuse alternative.

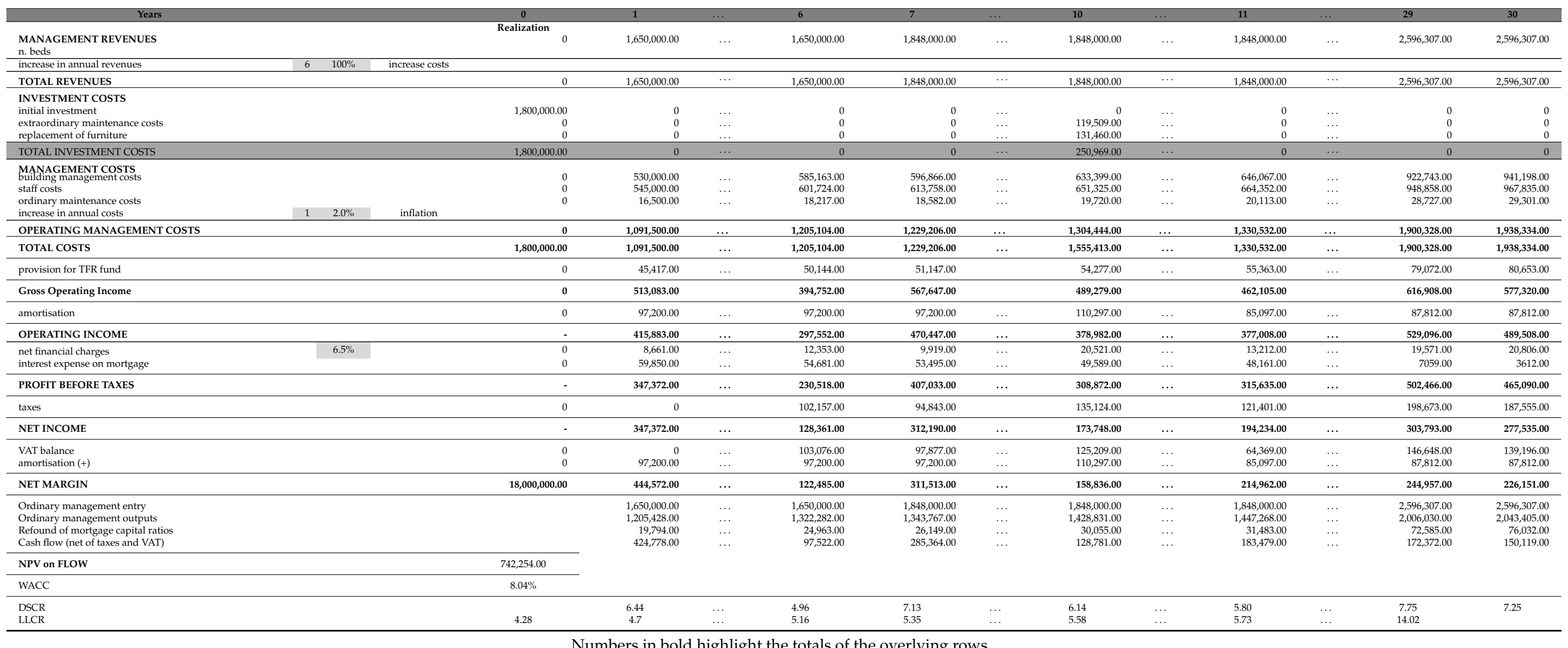

Numbers in bold highlight the totals of the overlying rows. 


\section{References}

1. United Nations General Assembly. Transforming Our World: The 2030 Agenda for Sustainable Development; United Nations, Department of Economic and Social Affairs: New York, NY, USA, 2015.

2. Bebbington, J.; Russell, S.; Thomson, I. Accounting and sustainable development: Reflections and propositions. Crit. Perspect. Account. 2017, 48, 21-34. [CrossRef]

3. Brandon, P.S.; Lombardi, P.; Shen, G. Future Challenges for Sustainable Development within the Built Environment; Wiley: Chichester UK, 2017.

4. Mondini, G. Valutazioni integrate per la gestione delle nuove sfide sociali. Valori Valutazioni 2016, 17, 15-17.

5. UN Environment. Global Status Report 2017: Towards a Zero-Emission, Efficient, and Resilient Buildings and Construction Sector. UN Environment and International Energy Agency. 2017. Available online: https://www.worldgbc.org/sites/default/ files/UNEP\%20188_GABC_en\%20\%28web\%29.pdf (accessed on 3 January 2021).

6. Della Spina, L.; Calabrò, F. (Eds.) Enhancement of Public Real-estate Assets and Cultural Heritage Management Plans and Models, Innovative Practices and Tools in Supporting the Local Sustainable Development; MDPI: Basel, Switzerland, 2020; Available online: https:/ / www.mdpi.com/books/pdfview/book/2731 (accessed on 2 December 2020). [CrossRef]

7. Centro Studi di Estimo e di Economia Territoriale. Atti della Tavola Rotonda su Contributo alla Stima dei Beni Immobili Pubblici, Centro Studi di Estimo e di Economia Territoriale: Firenze, Italy, 1988.

8. Fusco Girard, L. Capitale culturale intangibile e sviluppo locale "circolare". In Festività Carnevalizie, Valori Culturali Immateriali e Città Storiche. Una Risorsa per lo Sviluppo Turistico di Qualità del Mezzogiorno; Colletta, T., Ed.; Franco Angeli: Milano, Italy, 2018.

9. Fusco Girard, L. Energia, Bellezza, Partecipazione: La Sfida della Sostenibilità. Valutazioni Integrate tra Conservazione e Sviluppo; Franco Angeli: Milano, Italy, 2005.

10. Latham, D. Creative of Buildings; Donhead Publishing: Shaftesbury, UK, 2000.

11. MacArthur, E. Towards the Circular Economy, Economic and Business Rationale for an Accelerated Transition; Ellen MacArthur Found: Cowes, UK, 2013.

12. Ellen MacArthur Foundation and McKinsey Center for Business and Environment. Growth within: A circular Economy Vision for a Competitive Europe. 2015. Available online: https:/ /www.ellenmacarthurfoundation.org/assets/downloads / circulareconomy/Growth-Within-Report.pdf (accessed on 18 December 2020).

13. Dewiyana, E.; Ibrahim, N.; Hidayah, H.N. The Green Aspects of Adaptive Reuse of Hotel Penaga. Procedia Soc. Behav. Sci. 2016, 222, 631-643. [CrossRef]

14. Wu, H.; Hou, H.C. An investigation of private-owner-led heritage property adaptive reuse. In Proceedings of the 26th Pacific Rim Real Estate Society Annual Conference, Canberra, Australia, 19-22 January 2021; Pacific Rim Real Estate Society (PRRES), Taylor \& Francis: Oxfordshire, UK, 2021.

15. Permata, D.D.; Kuswandy, A.S.; Riza, A.I.; Sakti, P.F.; Diana, T.I. The centrum-bandung: Adaptive reuse at heritage building as sustainable architecture. IOP Conf. Ser. Earth Environ. Sci. 2020, 409, 012036. [CrossRef]

16. Conejos, S.; Yung, E.H.K.; Chan, E.H.W. Evaluation of urban sustainability and adaptive reuse of built heritage areas: A case study on conservation in Hong Kong's CBD. J. Des. Res. 2014, 12, 260-279. [CrossRef]

17. Elefante, C. The greenest building is one that is already built. Forum J. 2007, 21, 26.

18. Dyson, K.; Matthews, J.; Love, P.E.D. Critical success factors of adapting heritage buildings: An exploratory study. Built. Environ. Proj. Asset. Manag. 2016, 6, 44-57. [CrossRef]

19. Douglas, J. Building Adaptation, 2nd ed.; Butterworth-Heinemann: Oxford, UK, 2006.

20. Klamer, A. The values of cultural heritage. In Handbook on the Economics of Cultural Heritage; Ilde, R., Anna, M., Eds.; Edward Elgar Publishing: Cheltenham, UK, 2013; pp. 421-437.

21. Della Spina, L. Adaptive Sustainable Reuse for Cultural Heritage: A Multiple Criteria Decision Aiding Approach Supporting Urban Development Processes. Sustainability 2020, 12, 1363. [CrossRef]

22. Guarini, M.R.; Battisti, F. Benchmarking multi-criteria evaluation methodology's application for the definition of benchmarks in a negotiation-type public-private partnership. A case of study: The integrated action programmes of the Lazio Region. Int. J. Bus. Intell. Data Min. 2014, 9, 271-317. [CrossRef]

23. Del Giudice, V.; De Paola, P.; Torrieri, F. An integrated choice model for the evaluation of urban sustainable renewal scenarios. Adv. Mater. Res. 2014, 1030-1032, 2399-2406. [CrossRef]

24. Abastante, F.; Lami, I.M.; Mecca, B. How to revitalise a historic district: A stakeholders-oriented assessment framework of adaptive reuse. In Values and Functions for Future Cities. Green Energy and Technology; Mondini, G., Oppio, A., Stanghellini, S., Bottero, M., Abastante, F., Eds.; Springer: Cham, Switzerland, 2020; pp. 3-20.

25. Lami, I.M. Shapes, rules and values. In Abandoned Buildings in Contemporary Cities: Smart Conditions for Actions. Smart Innovation, Systems and Technologies; Lami, I.M., Ed.; Springer: Cham, Switzerland, 2020; Volume 168, pp. 149-162.

26. Bottero, M.; D'Alpaos, C.; Oppio, A. Ranking of adaptive reuse strategies for abandoned industrial heritage in vulnerable contexts: A multiple criteria decision aiding approach. Sustainability 2019, 11, 785. [CrossRef] 
27. Della Spina, L.; Giorno, C.; Galati Casmiro, R. An integrated decision support system to define the best scenario for the adaptive sustainable re-use of cultural heritage in Southern Italy. In New Metropolitan Perspectives; NMP 2020; Smart Innovation, Systems and Technologies; Bevilacqua, C., Calabrò, F., Della Spina, L., Eds.; Springer: Cham, Switzerland, 2020; Volume 177. [CrossRef]

28. Oppio, A.; Bottero, M. Conflicting values in designing adaptive reuse for cultural heritage. A case study of social multicriteria evaluation. In Computational Science and Its Applications-ICCSA 2017; ICCSA 2017; Lecture Notes in Computer Science; Gervasi, O., Murgante, B., Misra, S., Borruso, G., Torre, C.M., Rocha, A.M.A.C., Taniar, D., Apduhan, B.O., Stankova, E., et al., Eds.; Springer: Cham, Switzerland, 2017; Volume 10406, pp. 607-623.

29. Della Spina, L. Multidimensional Assessment for "Culture-Led" and "Community-Driven" Urban Regeneration as Driver for Trigger Economic Vitality in Urban Historic Centers. Sustainability 2019, 11, 7237. [CrossRef]

30. Calabrò, F.; Della Spina, L. The Public-Private Partnership for the Enhancement of Unused Public Buildings: An Experimental Model of Economic Feasibility Project. Sustainability 2019, 11, 5662. [CrossRef]

31. Oppio, A.; Bottero, M.; Ferretti, V. Designing adaptive reuse strategies for cultural heritage with choice experiments. In Appraisal: From Theory to Practice. Green Energy and Technology; Stanghellini, S., Morano, P., Bottero, M., Oppio, A., Eds.; Springer: Cham, Switzerland, 2017; pp. 303-315.

32. Della Spina, L. Historical cultural heritage: Decision making process and reuse scenarios for the enhancement of historic buildings. In New Metropolitan Perspectives; ISHT 2018; Smart Innovation, Systems and Technologies; Calabrò, F., Della Spina, L., Bevilacqua, C., Eds.; Springer: Cham, Switzerland, 2019; Volume 101. [CrossRef]

33. Della Spina, L.; Calabrò, F. Decision support model for conservation, reuse and valorization of the historic cultural heritage. In Computational Science and Its Applications-ICCSA 2018; ICCSA 2018; Lecture Notes in Computer Science, LNCS; Gervasi, O., Murgante, B., Misra, S., Borruso, G., Torre, C.M., Rocha, A.M.A.C., Taniar, D., Apduhan, B.O., Stankova, E., et al., Eds.; Springer: Cham, Switzerland, 2018; Volume 10962, pp. 3-17. [CrossRef]

34. Della Spina, L. Evaluation decision support models: Highest and Best Use choice. Procedia Soc. Behav. Sci. 2016. [CrossRef]

35. Tweed, A.C.; Sutherland, M. Built cultural heritage and sustainable urban development. Landsc. Urban Plan 2007, 83, 62-69. [CrossRef]

36. Pinto, M.R.; de Medici, S.; Senia, C.; Fabbricatti, K.; De Toro, P. Building reuse: Multi-criteria assessment for compatible design. Int. J. Des. Sci. Technol. 2017, 22, 165-193.

37. Simon, H. Theories of bounded rationality. In Decision and Organization; McGuire, C.B., Radner, R., Eds.; North-Holland Publications: Amsterdam, The Netherlands, 1972; pp. 161-176.

38. Misırlısoy, D.; Günçe, K. Adaptive re-use strategies for heritage buildings: A holistic approach. Sustain. Cities Soc. 2016, 26, 91-98. [CrossRef]

39. Council of Europe. Council of Europe Framework Monasteryion on the Value of Cultural Heritage for Society. 2005. Available online: https:/ / rm.coe.int/1680083746 (accessed on 3 January 2021).

40. Della Spina, L.; Giorno, C.; Galati Casmiro, R. Bottom-up processes for culture-led urban regeneration scenarios. In Computational Science and Its Applications-ICCSA 2019; ICCSA 2019; Lecture Notes in Computer Science, LNCS; Misra, S., Gervasi, O., Murgante, B., Stankova, E., Korkhov, V., Torre, C., Rocha, A.M.A.C., Taniar, D., Apduhan, B.O., Tarantino, E., Eds.; Springer: Cham, Switzerland, 2019; Volume 11622, pp. 93-107. [CrossRef]

41. Bazeley, P. Issues in mixing qualitative and quantitative approaches to research. In Applying Qualitative Methods to Marketing Management Research; Buber, R., Gadner, J., Richards, L., Eds.; Palgrave Macmillan: Basingstoke, UK, 2004; pp. 141-156.

42. Figueira, J.R.; Greco, S.; Ehrgott, M. (Eds.) Multiple Criteria Decision Analysis: State of the Art Surveys; Springer: Berlin/Heidelberg, Germany, 2005.

43. Tajani, F.; Morano, P.; Di Liddo, F.; Locurcio, M. Roles and risks of the subjects involved in public-private partnerships: The feasibility analysis of an enhancement investment in the city of Rome (Italy). LaborEst 2018, 16, 53-57.

44. Calabrò, F.; Della Spina, L. La fattibilità economica dei progetti nella pianificazione strategica, nella progettazione integrata, nel cultural planning, nei piani di gestione. Un modello sperimentale per la valorizzazione di immobili pubblici in Partenariato Pubblico Privato. LaborEst 2018, 16. [CrossRef]

45. Tajani, F.; Morano, P.; Liddo, F.D. Complementarieta'dei ruoli dei soggetti coinvolti in procedure di partenariato pubblico privato per l'efficacia degli interventi e la diversificazione dei rischi di mercato: Analisi di fattibilita'di un progetto di valorizzazione nella citta'di roma. LaborEst 2019, 18, 27-33.

46. Roscelli, R. (Ed.) Manuale di Estimo: Valutazioni Economiche ed Esercizio della Professione; UTET Università: Milano, Italy, 2014.

47. Celadyn, M. Interior Architectural Design for Adaptive Reuse in Application of Environmental Sustainability Principles. Sustainability 2019, 11, 3820. [CrossRef]

48. Della Spina, L. Scenarios for a sustainable valorisation of cultural landscape as driver of local development. In New Metropolitan Perspectives; ISHT 2018; Smart Innovation, Systems and Technologies; Calabrò, F., Della Spina, L., Bevilacqua, C., Eds.; Springer: Cham, Switzerland, 2019; Volume 100. [CrossRef]

49. Figueira, J.; Greco, S.; Roy, B.; Stowinski, R. An overview of ELECTRE methods and their recent extensions. J. Multi Criteria Decis. Anal. 2013, 20, 61-85. [CrossRef]

50. Hwang, C.L.; Yoon, K. Multiple Attribute Decision Making; Lecture Notes in Economics and Mathematical System; Springer: Berlin/Heidelberg, Germany, 1981; Volume 186. 
51. Opricovic, S.; Tzeng, G.H. Extended VIKOR method in comparison with outranking methods. Eur. J. Oper. Res. 2007, 178, 514-529. [CrossRef]

52. Roy, B. From Optimisation to Multicriteria Decision Aid: Three Main Operational Attitudes. In Multiple Criteria Decision Making; Lecture Notes in Economics and Mathematical Systems (Operations, Research); Thiriez, H., Zionts, S., Eds.; Springer: Berlin, Heidelberg, 1976; Volume 130.

53. Roy, B. Méthodologie Multicritére D'aide à la Decision; Economica: Paris, France, 1985.

54. Saaty, T.L. The Analytic Hierarchy Process; McGraw-Hill: New York, NY, USA, 1977.

55. Saaty, T.L. A Scaling Method for Priorities in Hierarchy Structures. J. Math. Psychol. 1980, 15, 234-281. [CrossRef]

56. Saaty, T.L. How to make a decision: The Analytic Hierarchy Process. Eur. J. Oper. Res. 1990, 48, 9-26. [CrossRef]

57. Saaty, T.L. Decision Making for Leaders: The Analytic Hierarchy Process for Decision in a Complex Word; RWS Publications: Pittsburg, CA, USA, 1999.

58. Tzeng, G.H.; Huang, J.J. Multiple Attribute Decision Making Methods and Applications; CRC Press, Taylor \& Francis Group: Boca Raton, FL, USA, 2011.

59. Velasquez, M.; Hester, P.T. An Analysis of Multi-Criteria Decision Making Methods. Int. J. Oper. Res. 2013, 10, 56-66.

60. Vincke, P. Multicriteria Decision-Aid; John Wiley \& Sons: Hoboken, NJ, USA, 1992.

61. Della Spina, L.; Rugolo, A. A multicriteria decision aid process for urban regeneration process of abandoned industrial areas. In New Metropolitan Perspectives; NMP 2020; Smart Innovation, Systems and Technologies; Bevilacqua, C., Calabrò, F., Della Spina, L., Eds.; Springer: Cham, Switzerland, 2021; Volume 178. [CrossRef]

62. Della Spina, L. Strategic planning and decision making: A case study for the integrated management of cultural heritage assets in Southern Italy. In New Metropolitan Perspectives; NMP 2020; Smart Innovation, Systems and Technologies; Bevilacqua, C., Calabrò, F., Della Spina, L., Eds.; Springer: Cham, Switzerland, 2020; Volume 1782021. [CrossRef]

63. Haroun, H.A.A.F.; Bakr, A.F.; Hasan, A.E.S. Multi-criteria decision making for adaptive reuse of heritage buildings: Aziza Fahmy Palace, Alexandria, Egypt. Alex. Eng. J. 2019, 58, 467-478. [CrossRef]

64. Chen, C.S.; Chiu, Y.H.; Tsai, L. Evaluating the adaptive reuse of historic buildings through multicriteria decision-making. Habitat Int. 2018, 81, 12-23. [CrossRef]

65. Claver, J.; García-Domínguez, A.; Sebastián, M.A. Decision-making methodologies for reuse of industrial assets. Complexity 2018. [CrossRef]

66. Turskis, Z.; Morkunaite, Z.; Kutut, V. A hybrid multiple criteria evaluation method of ranking of cultural heritage structures for renovation projects. Int. J. Strateg. Prop. Manag. 2017, 21, 318-329. [CrossRef]

67. Radziszewska-Zielina, E.; Ladowski, G.S. Supporting the selection of a variant of the adaptation of a historical building with the use of fuzzy modelling and structural analysis. J. Cult. Herit. 2017, 26, 53-63. [CrossRef]

68. Wang, H.J.; Zeng, Z.T. A multi-objective decision-making process for reuse selection of historic buildings. Expert Syst. Appl. 2010, 37, 1241-1249. [CrossRef]

69. Torrieri, F.; Fumo, M.; Sarnataro, M.; Ausiello, G. An integrated decision support system for the sustainable reuse of the former monastery of "ritiro del carmine" in campania region. Sustainability 2019, 11, 5244. [CrossRef]

70. Nestico, A.; Somma, P. Comparative analysis of multi-criteria methods for the enhancement of historical buildings. Sustainability 2019, 11, 4526. [CrossRef]

71. Pavlovskis, M.; Migilinskas, D.; Antucheviciene, J.; Kutut, V. Ranking of heritage building conversion alternatives by applying BIM and MCDM: A case of Sapieha Palace in Vilnius. Symmetry 2019, 11, 973. [CrossRef]

72. Nadkarni, R.R.; Puthuvayi, B. A comprehensive literature review of Multi-Criteria Decision Making methods in heritage buildings. J. Build. Eng. 2020, 32, 101814. [CrossRef]

73. Saaty, T.L.; Vargas, L.G. The analytic network process. In Processo Decisionale con il Processo di Rete Analitica; Serie Internazionale di Ricerca Operativa e Scienza Gestionale; Springer: Boston, MA, USA, 2013; Volume 195.

74. Saaty, T.L.; Vargas, L. Decision making with the analytic hierarchy process. 2008. Int. J. Serv. Sci. 2018, 1, 83-98.

75. Evangelos, T.; Mann, S.H. Using the analytic hierarchy process for decision making in engineering applications: Some challenges. Int. J. Ind. Eng. Appl. Pract. 1995, 2, 35-44.

76. Saaty, T.L. Decision Making for Leaders; RWS Publications: Pittsburgh, PA, USA, 1988.

77. Saaty, T.L.; Alexander, J.M. Conflict Resolution-The Analytic Hierarchy Process; RWS Publications: Pittsburgh, PA, USA, 1989.

78. Pierluigi, M.; Locurcio, M.; Tajani, F. Cultural heritage valorization: An application of AHP for the choice of the highest and best use. Procedia Soc. Behav. Sci. 2016, 223, 952-959.

79. Peter, J.M.; Love, E.D. Critical Success Factors of Adapting Heritage Buildings: An Exploratory Study. Built Environ. Proj. Asset Manag. 2015. [CrossRef]

80. Pickard, R. Management strategies for historic towns in Europe. Urban heritage. Dev. Sustain. Int. Fram. Natl. Local Gov. 2016, 151-174.

81. Vahtikari, T. Valuing World Heritage Cities; Routledge: Oxon, UK; New York, NY, USA, 2017; ISBN 1317002598.

82. Sonkoly, G.; Vahtikari, T. Innovation in Cultural Heritage: For an Integrated European Research Policy; European Commission Publications Office: Luxembourg, 2018; ISBN 9279780190.

83. OECD. Recommendation of the Council on Principles for Public Governance of Public-Private Partnerships. 2012. Available online: https:/ / legalinstruments.oecd.org/public/doc/275/275.en.pdf (accessed on 4 January 2021). 
84. Osborne, S. Public-Private Partnerships: Theory and Practice in International Perspective; Routledge: London, UK, 2000.

85. Leung, Y.B.; Hui, C.E. Evaluation approach on public-private partnership (PPP) urban redevelopments. Int. J. Strateg. Prop. Manag. 2005, 9, 1-16. [CrossRef]

86. Tajani, F.; Morano, P. Concession and lease or sale? A model for the enhancement of public properties in disuse or underutilized WSEAS Trans. Bus. Econ. 2014, 11, 787-800.

87. Parmentola, N.; Rotondo, S. (Eds.) Interventi Pubblici e Processi Decisionali; Formez: Naples, Italy, $2004 ;$ pp. 85-103.

88. Abatecola, G.; Mari, M.; Poggesi, S. How can virtuous real estate public-private partnerships be developed? Towards a co-evolutionary perspective. Cities 2020, 107, 102896. [CrossRef]

89. Battisti, F.; Campo, O. A Methodology for Determining the Profitability Index of Real Estate Initiatives Involving Public-Private Partnerships. A Case Study: The Integrated Intervention Programs in Rome. Sustainability 2019, 11, 1371. [CrossRef]

90. Romero, M.J. What lies beneath? A critical assessment of PPPs and their impact on sustainable development. Eurodad 2015. Available online: http:/ / www.eurodad.org/files/pdf/559da257b02ed.pdf (accessed on 4 January 2021).

91. Valenza, A.; Vignetti, S. Analisi Finanziaria Dei Progetti Di Intervento Pubblico. In Interventi Pubblici e Processi Decisionali; Parmentola, N., Rotondo, S., Eds.; Formez: Naples, Italy, 2004; pp. 85-103.

92. Prizzon, F. Gli Investimenti Immobiliari. Analisi di Mercato e Valutazione Economico-Finanziaria degli Interventi; Celid: Torino, Italy, 1995.

93. Carbonara, N.; Costantino, N.; Pellegrino, R. Concession period for PPPs: A win-win model for a fair risk sharing. Int. J. Proj. Manag. 2014, 32, 1223-1232. [CrossRef]

94. Nijkamp, P.; Rietveld, P.; Voogd, H. Multicriteria Evaluation in Physical Planning; North Holland Publications: Amsterdam, The Netherland, 1990.

95. UNESCO. Budapest Declaration on Word Heritage; UNESCO: Budapest, Hungary, 2002.

96. Chan, E.H.W.; Lee, G.K.L. Critical factors for improving social sustainability of urban renewal projects. Soc. Indic. Res. 2007, 85, 243-256. [CrossRef]

97. Zancheti, S.; Hidaka, L. Measuring urban heritage conservation: Indicator, weights and instruments (part. 2). J. Cult. Herit. Manag. Sustain. Dev. 2012, 2, 15-16. [CrossRef]

98. Phillips, R.G.; Stein, J.M. An indicator framework for linking historic preservation and community economic development. Soc. Indic. Res. 2013, 113, 1-15. [CrossRef]

99. Spina, L.D.; Calabrò, F. Processo Edilizio e Stima dei Costi. LaborEst 2015, 11_IS, 3-22.

100. Rivett, P.; Coopers \& Lybrand. The Financial Jungle: A Guide to Financial Instruments; IFR Publication: New York, NY, USA, 1991. 